\title{
Measuring Basic Psychological Need Satisfaction and Frustration and Work Engagement of Employees of Divine Word Colleges in Ilocos Region, Philippines
}

\author{
Damianus Abun ${ }^{1}$, Ph.D, Theogenia Magallanez², Ed.D, Sylvia Lalaine Grace L. \\ Foronda ${ }^{3}$, Ph.D, Frederic Agoot ${ }^{4}$, MAME \\ ${ }^{1}$ Divine Word College of Vigan, Philippines and St. Benedict College of Northern Luzon, Philippines \\ ${ }^{2}$ St. Benedict College of Northern Luzon, Philippines \\ ${ }^{3}$ Faculty of the College of Business Administration of Divine Word College of Laoag, Ilocos Norte, Philippines \\ ${ }^{4}$ Divine Word College of Vigan, Philippines
}

\begin{abstract}
The study wants to determine the effect of basic psychological need satisfaction and basic psychological need frustration toward work engagement of employees of Divine Word Colleges in Ilocos Region, Philippines. In order to support the study, theories were presented which are supported by related literatures and studies. The population of the study were 250 or all employees of the colleges. The study used descriptive correlational research design aided by fact finding inquiry. Questionnaires were used to gather the data. The result revealed that there is a correlation between basic psychological need satisfaction and work engagement. While, basic psychological need frustration, as a whole, does not correlate to the engagement, except relatedness need frustration.

Keywords-Basic psychological need satisfaction, basic psychological need frustration, autonomy, relatedness, competency.
\end{abstract}

Self-Determination Theory (Deci \& Ryan, 1985, 2000) opens the way to investigate the basic psychological need satisfaction and frustration of employees and its effect of work engagement. The SDT is a broad theory of motivation which is composed of intrinsic and intrinsic motivation. Motivation is no longer treated as a unitary concept, but it has been classified into intrinsic and extrinsic. Intrinsic motivation is part of basic psychological need which is composed of autonomy, relatedness and competence needs. These needs are innate in nature, but it needs supportive social environment for the needs to grow.

Human beings are born with the three needs, but those needs can be frustrated where workplace environment is not supportive to the realization of autonomy, relatedness and competence need. The fulfillment of basic psychological needs and the frustration can become problem for the organizational objectives and performance. However, there have been few studies pointed out to the effect of basic psychological need satisfaction and frustration to the work engagement of employees (Abun \& Magallanes, 2018, Suzuki \& Nashimura, 2016).

Many studies have been done in investigating motivation and its effect of job performance, but those studies are related to external motivation, not intrinsic motivation. In line with the concept and concern, the current study is dealing closely with the investigation of intrinsic motivation in line with the satisfaction of basic psychological needs and the frustration of the three needs and how they affect the work engagement of employees.

Significance of the Study

The study is important to the management for policy decision making in terms of looking into important factors to be considered in motivating employees. Many policies related to salaries and benefits that are provided for employees are originated in the concept of extrinsic motivation and neglect the intrinsic element of motivation. By knowing intrinsic motivation as important factors in motivating employees, the management can look into providing workplace policies that are supportive to the growth of basic psychological needs and consequently for the improvement of organizational performance.

Theoretical Framework 


\section{Humanistic and Incentive Theory of Motivation}

Humanistic and incentive theories of motivation refer to the force behind a person's level of energy to work. It is what causes a person to act or not to act, to work hard or not to work hard. Humanistic theory of motivation is discussed very well in the Maslow's (1943) hierarchy of needs, Herzberg (1959) and McClelland (1988). In general, these theories discussed extrinsic theories of motivation. Maslow (1943) argued that human action is directed toward goal attainment and at the same time satisfy certain human needs. He then presented the hierarchy of needs such as physiological, safety, belongingness, esteem and selfactualization. According to Maslow's theory, an employee is motivated by lower level needs before moving to the higher-level needs. One the basic needs are secured; the next level is security or safety. In this level, employees seek to be secured or safe in terms health, well-being, danger and employment. Only after this need is fulfilled, then the employee moves to higher need such as love or belongingness. The employee seeks to build relationship with others and want to be loved and accepted by another group. This need moves the employee to the next level of need that is self-esteem, in which the employee needs selfconfidence and respect from others. Once this need is attained, the employee looks for self-actualization. The employee works to realize his/her full-potentials.

Herzberg, et.al (1959) presented two factor theory. He argued that there are factors in the workplace that could motivate employees to work harder and there are also factors that could de- motivate employees if they are not present, though these factors do not directly motivate employees. Those two factors are called motivator and hygiene factors. Motivators are challenging task, achievement, responsibility to do something meaningful, sense of importance, opportunity to contribute something meaningful. Hygiene factors include job security, working condition, employment status, vacations, etc. However, the presence of hygiene factors does not directly affect the satisfaction and motivation, but their absence can affect the satisfaction. In conclusion, Herzberg recommended that in order to motivate employees to work harder and smarter, the manager needs to improve the motivator and the hygiene factors

In line with the Maslow's hierarchy theory, McClelland (1988) presented three kinds of needs namely achievement, affiliation and power needs. McClelland's theory is similar to Maslow hierarchy's theory of needs. However, Maslow's hierarchy of needs are structured, one after the other, in the sense that one cannot move to the next level of needs unless the lower level needs are fulfilled. However, in
McClelland's theory, the needs are not structured, and an employee can fulfill these needs at the same time. Employee can seek higher needs at the same time with lower needs. According to this theory, employees who are driven by the need for achievement prefer work in which the results are based on their effort rather than on anything else and avoid both high-risk and low-risk situations. They also recognize the importance of working relationship in attaining their goals and therefore these employees often spend time creating and maintaining social relationships, enjoy being a part of groups, and have a desire to feel loved and accepted. There are also some employees who are driven by the need for power. These employees like to be in charge, to control, to supervise others. Employees in this category enjoy work and place a high value on discipline.

The business has recognized the important contribution of motivation toward the attainment of organizational goals or objectives. Many have recognized that goals cannot be achieved through controlling management style and they cannot be achieved through possessing qualifications and abilities, but they are achieved through motivated employees. Though employees have the qualifications and abilities but if they do not have proper motivations, goals cannot be achieved. For bringing out the best in people, one has to be motivated to work (MSG, n.d). Nasibov (2015) argues that high productivity is a product of employees' motivation. Employee motivation is viewed as a valuable asset which contributes high value to the attainment of organizational goals. Broni (2012) also argued along the same line of findings that lack of motivation is the biggest contribution to the decrease in the performance of employees. Therefore, he recommended that the management should develop some programs that will improve the motivation of employees. Also, as a result of a study, the same recommendations are also forwarded by Singh (2011), Mensah and Tawiah (2013) that management needs to identify different factors within the organization that enhance motivation of employees such as benefits and salaries and other factors that maintain the level of motivation of employees.

\section{Self-Determination Theory of Motivation}

Theories presented above tend to discuss motivation as a unitary concept. However, other theorists have discussed motivation not as a unitary concept. There has been effort to go away from treating motivation as a single concept into classifying motivation as intrinsic and extrinsic motivation such as White (1959) and Harter (1978) as cited by Schunk (2014) and many more. White (1959) defined intrinsic motivation as the desire of an individual to participate in the 
activity just for the joy of learning, while extrinsic motivation is joining the activity because of external rewards such as praise. Harter (1978) holds most of White's idea about motivation but she argued that the effects resulting from failure is an important contribution to motivation.

Other efforts in classifying motivation into different categories are Deci (1971, 1975), Deci and Ryan (1985). Ryan and Deci $(1985,2000)$ classified motivation as an extrinsic and intrinsic motivation. According to Deci and Ryan (1985, 2000), an individual's behavior may be motivated by external demands or forces or it may be coming from within the individual himself. The previous studies of Deci and Ryan (, 1971, 1975, 1985) resulted to the formulation of the Self-Determination Theory. It is a macro theory or broader theory of human motivation and personality that concerns people's inherent growth tendencies and innate psychological needs. The arena of Self-Determination Theory is the investigation of people's inherent growth tendencies and innate psychological needs which are the basis for their self-motivation and personality integration. Under Self-Determination theory, Deci and Ryan, (2000), identified three basic psychological needs and these are autonomy (deCharms, 1968), relatedness (Baumeister, \& Leary, 1995) and competence (Harter, 1978). These three needs are innate needs or intrinsic motivational needs and considered important in promoting optimal functioning of natural tendencies for growth and integration. Deci and Ryan (2000) argued that social and cultural factors facilitate or undermine people's sense of volition and initiative which affect well-being and quality of life. Concerning the context in which the intrinsic needs are cultivated, Cognitive Evaluation Theory (CET) addresses the effect of social contexts on intrinsic motivation or how external control impact intrinsic motivation and interest. Related to the optimal functioning and well-being, Basic Psychological Need Theory (BPNT) argues that psychological well-being and optimal functioning is predicated on autonomy, competence and relatedness. These three needs are essential and therefore the supportive environment for the growth of these needs are necessary because if one of these needs are thwarted, not supported, there will be distinct functional cost.

Autonomy is a psychological need and a motivation.

Webster defines autonomy as "the quality or state of being self-governing; especially: the right of selfgovernment" or," self-directing freedom and especially moral independence". Based on this definition, it is pretty clear that autonomy is considered as a psychological need that everyone needs to actualize. Legault (2016) argued that autonomy is a critical psychological need. It denotes the experience of volition and self-direction in thoughts, feeling and actions. It is the freedom to control one's life and self. The locus of control is the person himself/herself that he/she controls the outcome of his/her situation. It is the ability to make choices according to one's own free will (Lickerman, 2012). It allows individual to have individual freedom and to be creative as they can to get what they want to achieve. Collier (n.d) argued that autonomy is the foundation of functionality, intentionality and meaning. It is a selforganizing process. Piaget argues that autonomy is an innerdirected behavior as a result from free decision. It is an intrinsic motivation and therefore rules are self-chosen. One chooses which rules to follow and therefore one determines his/her own behavior. Piaget's idea on autonomy was a result of studying cognitive development of children and concluded that the children moral maturation process occurs in two phases which is heteronomous and autonomous reasoning. Heteronomous reasoning explains that children believe that rules are objective and unchanging. Rules must be followed literally without discussion because the authority is ordering it. Autonomous reasoning, however, is contrary to heteronomous reasoning. At the autonomous reasoning, children are no longer seeing the rules as objective and unchanging and follow them literally, but they see rules as the product of agreement and therefore modifiable. Rules can be revised, and it is subject to interpretation. The base of the rules is its own acceptance and its meaning must be explained (Sugarman, 1990).

Cooper (2016) claimed that the key to happiness at work is not money but autonomy. It is having a job where the employees can make decisions on their own. Employees have the choices to choose what they want to do based on their own volition and that they are the source of their own actions. They drive toward feeling self-directed and selfdetermined in their life. There is a sense of personal endorsement of their goals and actions. He further argued that the more autonomous the employees are at work, the more satisfied they are at their work and less likely to transfer to find another job. This autonomy reflects a personal trait and motivation because an individual has a sense of volition and self-concordance in his life and at the same time have sense of volition and concordance in his work because of autonomy support. The workplace that supports autonomy may help employees progress in his work. The experience of autonomy in the workplace motivates the person to work harder and to stay loyal to the company (Legault, 2016).

In short, autonomy is a natural inclination that is built in a person and a source of motivation (Deci \& Ryan, 1995). In 
the first place, all humans are born with such trait by which they exercise their volition and direct themselves without external force. Secondly, autonomy is a source of motivation. When a person is not given a chance to grow autonomously, the person may not be satisfied. Therefore, autonomy as a personal trait must be nurtured by providing an environment where autonomy can grow. When the workplace is supporting autonomy, employees may result to higher job satisfaction (Dickinson, 1995, pp. 165-174, Legault, 2016). Autonomy may not be a direct motivation why people work but the absence of the environment that support the growth of autonomy may affect the motivation of people to work.

\section{Relatedness as a Psychological need and motivation.}

Webster dictionary defines relatedness as "having close harmonic connection". The same definition is given by the Free Dictionary that relatedness is a "close harmonic connection". Oxford Learner's Dictionary defines relatedness as "the fact of being connected with something/somebody in some way". "It is a sense of relatedness and interdependence of life". However, in Psychology Dictionary, relatedness is defined as "a reciprocity of factors like trust and empathy between two or more persons in a relationship". All these definitions refer to social relatedness which means interpersonal intimacy, empathy and shared subjectivity.

Relatedness as a need was already identified by Alderfer (1969). In an attempt to simplify Maslow's hierarchy of needs, Alderfer identifies three kinds of needs and they are existence, relatedness and growth. These three needs are already within the scope of Maslow's hierarchy theory of needs, however, Alderfer argued that needs are not in any order and any desire to fulfill a need can be activated at any point in time (Furnham, 1994). It does not need to follow the order, but one can pursue any needs at the same time. Existence relates to person's physiological and safety needs such as foods, clothing, shelter, and security and without these basic needs people cannot survive. These are the first two steps of the pyramid which people now use to represent Maslow's theory (Quigley, 2015). Relatedness refers to person's interpersonal needs within his personal as well as professional settings. The needs are equal to the social and external esteem needs such as relationships or involvement with friends, family, and co-workers which is part of the third and fourth rank of Maslow's hierarchy of needs. Growth is a person's needs of personal development. This need represents the internal esteem and self-actualization needs of Maslow. ERG theory of needs is simplification of five needs of Maslow such as physiological, safety, belongingness, recognition/esteem and self-actualization.

Relatedness is an inner need of each human being to care about and be cared about by others. It is natural and psychological need to be connected without ulterior motives. It has something to do with the development and maintenance of close personal relationship such as friends, partners, or groups. Such need is not only belonged to one person, but it is universal, that all people want to interact, be connected to, and experience caring for others and to be cared by others. Alderfer (1969) argued that it is a social and external esteem. It is a need to be involved with family, friends, co-workers and employers. Under the Selfdetermination theory, relatedness is classified as one of the cores of the innate psychological needs of a person to be satisfied (Deci\& Ryan, 2000). It is argued that each human being has an innate need to connect to other people. Each has a need to love and to care other persons and need to be loved and to be cared for. The need for relatedness motivates people to engage in mutually enjoyable activities from which we derive both pleasure and a sense of connectedness and shared experience. Through common activities a person experience support from peers, experience a cooperation, and receives mutual rewards (Rigby \&Ryan, 2011). In the common activities a person fulfills his/her need to be listened to and get others' attention. The need to be connected to is fulfilled. However, the common activities must provide an environment in which the relatedness need is realized. Relationship Motivation Theory (RMT), a sub theory of SDT argues that some amount of interactions is not only desirable for most people, but it is essential for the well-being because it satisfies the relatedness need of a human being.

\section{Competence Need is a Psychological need and} motivation

Competence is one of the three basic psychological need that is innate in each human being. It is a natural desire of all human beings that needs to be satisfied. It is argued that people have a need to build their competence and develop a mastery over as certain task that are important to them (Sagor, 2003).Legault (2017) argues that the desire to satisfy the need for competence motivate people to persist, maintain efforts and self-determination to continue to improve one's skills and abilities. It can be shown in the behavior of people who never surrender to external criticism. Studies have also found that satisfying autonomy and competence need will improve the level of engagement, intrinsic motivation, low proneness to negative effect, and achievement ((Jang, et al, 2009). 
Competence is the innate propensity to develop skill and ability, and to experience the effect or the output of certain action (Legault, 2017). The ability to meet the optimal challenge is fulfilling or satisfying. It is further deeply satisfying experiences and is essential for psychological growth and well-being. This need does not grow by itself. Developing such need depends on the social and cultural environment which support competence need. Criticism coming from the management and peers can hamper the satisfaction of competence need. Deci (1971) in his study found that giving people unexpected positive feedback on a task increases people's intrinsic motivation to do it, the feeling of competence is satisfied. In fact, giving positive feedback on a task served only to increase people's intrinsic motivation and decreased extrinsic motivation for the task. While giving negative feedback will hamper the fulfillment of the intrinsic motivation and hinder the realization of competence need. Vallerand and Reid (1984)found negative feedback has the opposite effect. It decreases intrinsic motivation by discouraging people to develop their competence need.

\section{Psychological need Frustration}

Within Basic Psychological Needs Theory, a sub theory of Self-determination Theory (SDT) (Deci and Ryan 2000; Ryan and Deci, 2000), that there are three kinds of innate psychological need and they are autonomy, relatedness and competence. It is argued that the satisfaction of these psychological needs is essential for human optimal functioning and well-being (Ryan \& Deci, 2000). In contrast, when these needs get frustrated, can result to demotivation (Ryan et al. Vansteenkiste and Ryan, 2013). It is believed that all humans are equipped with the innate psychological tendency. The satisfaction of the three needs are essential for the integration process of extrinsic motivation and promotes well-being. When these needs are not supported, they would hamper the growth of an individual, elicit deficiencies and ill-being.

The need for autonomy is a need to control one's own life and self. It is a need that one wants to control the outcome of a situation. It is the experience of self-determination, full willingness, and volition when carrying out an activity. This need is frustrated when one has no hold on his decision, direction and the outcome of a situation because of external pressures ((deCharms 1968, Deci and Ryan 1985). While relatedness is the inner desire to interact, be connected to, and experience caring for others and to be cared by others (Ryan, 1995). When this need is not fulfilled or frustrated, the individual experiences isolation and loneliness. Competence need involves feeling of mastery, skillful, effective and capable to achieve desired outcomes ((Deci
1975, Ryan, 1995). The frustration of the need means that one can feel incompetent, and doubtful of his/her selfefficacy.

\section{Work Engagement}

Work engagement is about understanding one's role in an organization and about one's excitement to take up the job to pursue organizational objectives. Those who are engaged in their work feel that they are part of the team to carry out the work and willing to take all efforts they can to accomplish their tasks. May, et.al (2004) argued that employee who are engaged employing and expressing themselves physically, cognitively, emotionally and mentally during role performances. They claim that there are three aspects of work motivation and these are cognitive, emotional and physical engagement. In this case, work engagement is considered as a "positive, fulfilling, work-related state of mind that is characterized by vigor, dedication, and absorption" (Schaufeli, et.al, 2002). It is not only about physical connection to the work, but it is also emotional connection, as pointed out by Bakker (2011) that work engagement is also about psychological connection with the work. He argued that competition is the game of the business today and the only way to win this game is not only to recruit talents but inspire employees to apply their talents fully to their work. According to Bakker (2011) engaged employees have positive attitude toward their work and are happy to hear feedbacks and even create their own feedbacks. They do not see work as burdens but a challenge to their capabilities

Making employees engaged is not the same as making employees happy because often time employees are happy at work, but it does not mean they are engaging in their work. It is also argued that engaged employees is not the same as satisfied employees because the satisfied employee might show up for work, do the job regularly but he/she does not go extra miles on her own to carry out the job beyond what is required in the job description (Kruse, 2012).It is not the same as workaholism (Schaufeli, 2011). Thus, engagement is about emotional connection or psychologicalconnection of the person toward his/her work. She/he works not for money but works on behalf of the organization's goals or objectives. These are the people who approach their work with energy, dedication and focus and are willing to go beyond what is written in their job description. However, it is also pointed out that work engagement is an intrinsic motivation, but it must be supported by positive social environment where employees feel the social support from peers and management, receive positive feedback, enjoy the autonomy and receive personal growth support (Bakker, 2011). 


\section{Related Studies}

After checking related studies that support the current topic, the researcher found several related studies on the topic particularly on the relationship between basic psychological need satisfaction, frustration and work engagement. Common findings of those studies support the assumption of the study that satisfaction of the basic psychological needs is essential, not only to work engagement but also to well-being and optimal functioning of an individual.

Related to psychological need satisfaction and work engagement and work intention, Schuck and Zigarmi (2015) found the significant relations between psychological need satisfaction and engagement. It was also found that there was a significant relationship between basic psychological need satisfaction and work intention. Similar study was done by Broeck, Marteen, De Wette and Lens (2008). They tried to explain the role of basic psychological need satisfaction toward job burnout and work engagement. Findings indicate of their study that there is a relationship between satisfaction of basic psychological need and job burnout and work engagement. Related finding was also forwarded by Gagne (2003). Gagne tried to investigate social environment that support autonomy and how it affects engagement in pro social behavior. The study confirms that the findings of other studies that autonomy support and autonomy orientation was significantly related to engagement in pro social behavior. This is likewise presented by the study of Arshadi (2010) in which found that satisfaction of basic psychological needs predicts motivation and job performance. These studies have concluded that satisfying basic psychological need such as autonomy, relatedness and competent are important in improving work engagement and even to the goal orientation (Sari, 2015).

Given those findings, Abun and Magallanes pursued similar study to find out the effect of the fulfillment of basic psychological need such as autonomy, competence and relatedness and its effect on work engagement in the Philippine context. The finding of the study is quite different from the result of other studies that not all three basic psychological need satisfaction related to work engagement. It was found that autonomy and competence was not significantly related to work engagement, but relatedness do have a significant relationship with work engagement. This finding seems to be supported by other study of Xiang, Agbuga, Liu and McBride (2017) on the relationship between relatedness need satisfaction, intrinsic motivation and engagement. The study supports the finding of Abun and Magallanes (2018) that relatedness need satisfaction made a significant contribution to students' engagement for both, boys and girls. In the same regard, Perry, et.al (2012) conducted a study on teachers' relatedness need with the students and colleagues and how it affects their teaching engagement. Their study found that relatedness need satisfaction predicts teaching engagement and emotional exhaustion as also pointed out by Molinari and Maneli (2018), who studied on basic psychological needs of students and engagement in Secondary Schools in Italy. The study confirms that satisfaction of psychological needs enhances students' engagement.

In terms of the relationship of basic psychological need satisfaction and job satisfaction, studies have found that basic psychological need satisfaction affect job satisfaction. For example, Busch and Hofer (2011) conducted a study on satisfying one's need for competence, and relatedness and job satisfaction. The study concluded that the satisfaction of the needs for competence and relatedness is linked to higher level of job and relationship satisfaction among individuals with strong implicit motives. The same interest of study was also done by Sheldon and Filak (2008) on autonomy, competence and relatedness support. The study presented similar output that satisfaction of the competence, relatedness and autonomy needs predict the outcome and job satisfaction. Their other finding also indicated that thwarting those psychological needs can affect outcome.

The satisfaction of basic psychological needs is not only affecting work engagement and job satisfaction, even they affect also well-being of the individuals. Related to this concern, Molix and Nichols (2013) conducted a study on the satisfaction of basic psychological need and community esteem and well-being. The study concluded that there is a robust association between community esteem and both hedonic and eudaimonic measures of well-being. In this regard, Suzuki and Nashimura (2016) went into a study on basic psychological need satisfaction and frustration and well-being in Japan. The study concluded that satisfaction of each of the three needs contributed to the prediction of subjective well-being such as life satisfaction and vitality, whereas frustration of each need uniquely contributed to the prediction of ill-being such as depressed affect.

The above studies have pointed out the effect of basic psychological need satisfaction and job engagement, but those studies have not given serious attention to the frustration of basic psychological need and its effect on the job engagement. The current study tries to see the two variables and how they affect the job satisfaction. 


\section{Conceptual Framework \\ Independent Variables}

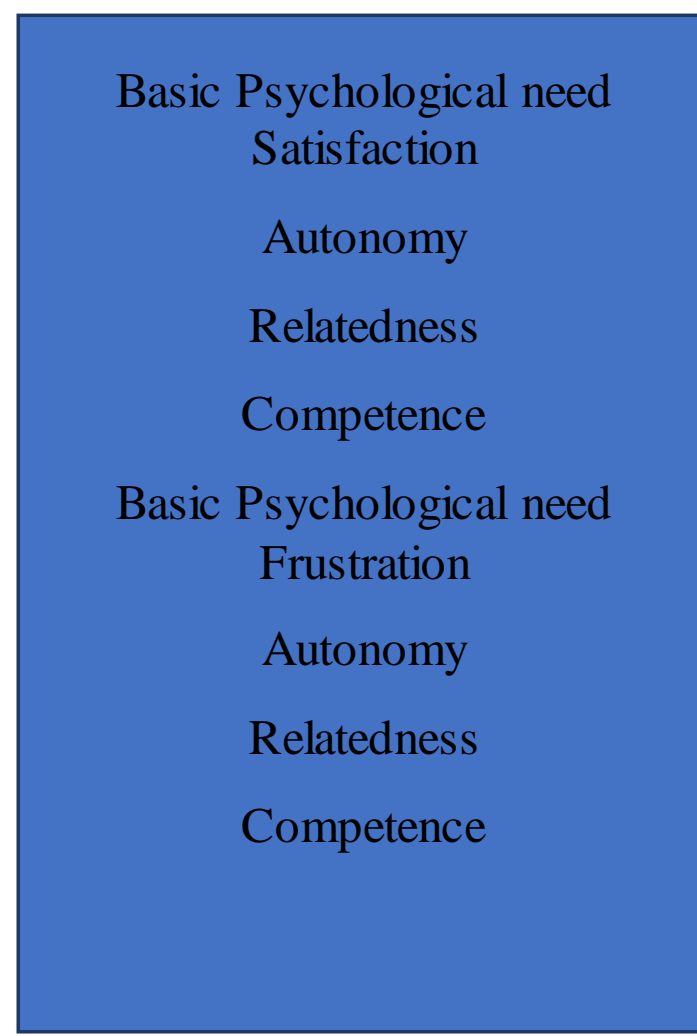

Dependent Variables

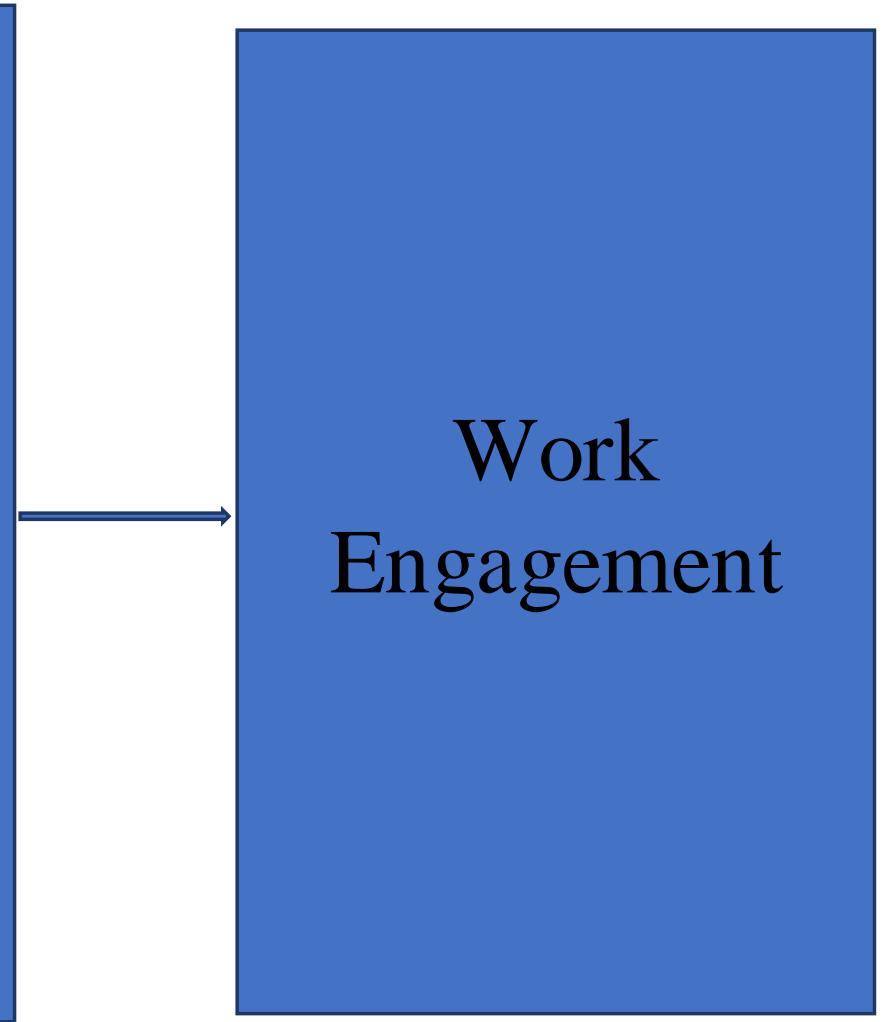

Fig.1: The conceptual framework reflects the theory of the study, that basic psychological satisfaction and frustration affects the work engagement of employees of Divine Word Colleges in Ilocos Sur and Ilocos Norte.

\section{Statement of the Problems}

The study would like to determine the relationship between basic psychological need satisfaction and frustration and how it affects the work engagement of employees, specifically it seeks to answer the following questions:

1. What is the basic psychological need satisfaction of employees in terms of
a. Autonomy
b. Relatedness
c. Competence?

2. What is the basic psychological need frustration of employees in terms of
a. Autonomy
b. Relatedness
c. Competence?

3. What is the work engagement of employees?

4. Is there a significant relationship between basic psychological need satisfaction, and work engagement?

5. Is there a relationship between basic psychological need frustration and work engagement?
Assumption of the Study

The study is guided by the assumption that the relationship between basic psychological need satisfaction, frustration and work engagement can be measured and the questionnaires used are valid and the answers are honest.

\section{Hypothesis}

Studies have been made by other researchers that there is a relationship between basic psychological need satisfaction and work engagement (Broeck, Marteen, De Wette and Lens (2008, Gagne (2003, Arshadi 2010) and therefore the study hypothesizes that basic psychological need satisfaction and frustration affect the work engagement.

\section{Scope and delimitation of the Study}

The current study limits itself to the employees of Divine Word Colleges in Ilocos Region, particularly Divine Word College of Laoag and Divine Word College of Vigan. The study covers the basic psychological need satisfaction and frustration of basic psychological need and work engagement.

\section{Research Methodology}


To carry out the study, an appropriate research methodology is utilized. Therefore, this part will discuss research design, data gathering instruments, population, locale of the study, data gathering procedures and statistical treatment of data.

\section{Research Design}

Since the study is a quantitative research, thus, the study used descriptive correlational research designand aided by inquiry to determine the level of basic psychological need satisfaction and frustration and its effect on work engagement of employees. The nature descriptive is to describe what is found in the data collected through questionnaires and statistical treatment. It is also used to describe profiles, frequency distribution, describe characteristics of people, situation, phenomena or relationship variables. In short, it describes "what is" about the data (Ariola, 2006).

In line with the current study, descriptive correlational method was deployed. The study determines the level of basic psychological need satisfaction and frustration and how it affects their work engagement. This was to determine what the dominant basic psychological need satisfaction and frustration among employees were and what basic psychological need satisfaction and frustration affects the work engagement of employees.

\section{Locale of the Study}

The locale of the study was Divine Word Colleges in Region I which is composed of Divine Word College of Vigan. Divine Word College of Vigan belonged to the Province of Ilocos Sur and located within the heritage city of Vigan. Divine Word College of Laoag is in Laoag City, Ilocos Norte. Divine Word Colleges in region I are run by the Congregation of the Divine Word Missionaries or known as Society of the Divine Word or in Latin, Societas VerbiDivini (SVD).

\section{Population}

The population of the study was composed of all employees, teaching and non-teaching, of Divine Word Colleges in Ilocos region. Since the total numbers of employees are limited, and therefore total enumeration is the sampling design of the study.

\section{Data Gathering instruments}

The study utilized questionnaires. The questionnaires were adapted from Basic Psychological Need satisfaction and Frustration Scale (Chen, 2015) to assess needs satisfaction and frustration at work. While questionnaires on work engagement were adapted from Abun (2018).

\section{Data Gathering Procedures}

In the process of data gathering, the researcher sent letters to the President of the Colleges, requesting them to allow the researcher to flow his questionnaires in the college. The researcher personally met the Presidents and students and requested them to answer the questionnaires.

The retrieval of questionnaires was arranged between the President's representative and the researcher with the help of employees and faculty of the college.

\section{Statistical Treatment of Data}

In consistent with the study as descriptive research, therefore descriptive statistics is used. The weighted mean and the Pears on $r$ will be used to measure the level of entrepreneurial attitudes and intentions and their correlations with the work engagement.

The following ranges of values with their descriptive interpretation will be used:

$\begin{array}{lll}\text { Statistical Range } & \text { Descriptive Interpretation } & \text { Overall Descriptive Rating } \\ 4.21-5.00 & \text { Stronglyagree/Very satisfied } & \text { Very High } \\ 3.41-4.20 & \text { Agree/satisfied/ } & \text { High } \\ 2.61-3.40 & \text { Somewhat agree/Somewhat satisfied } & \text { Moderate } \\ 1.81-2.60 & \text { Disagree/dissatisfied } & \text { Low/High } \\ 1.00-1.80 & \text { Strongly disagree/very dissatisfied } & \text { Very Low/Very High } \\ & & \\ 4.21-5.00 & \text { Strongly agree/Very frustrated } & \text { Very high } \\ 3.41-4.20 & \text { Agree/frustrated } & \text { High } \\ 2.61-3.40 & \text { Somewhat agree/somewhat frustrated } & \text { Moderate } \\ 1.81-2.60 & \text { Disagree/not frustrated } & \text { Low } \\ 1.00-1.80 & \text { Strongly disagree/not frustrated at all } . & \text { Very low }\end{array}$

Findings, conclusion and recommendation

The finding of the study is presented according to the statement of the problems of the study. 
Problem 1a. What is the basic psychological need satisfaction of employees of Divine Word Colleges in Ilocos Region in terms of autonomy?

Table.1a. Autonomy Satisfaction

\begin{tabular}{|l|l|l|}
\hline Autonomy Satisfaction & X & DR \\
\hline $\begin{array}{l}\text { 1. At work, I feel a sense of choice and freedom in the things I } \\
\text { undertake. }\end{array}$ & 3.64 & Agree/Satisfied/High \\
\hline 2. I feel that my decisions on my job reflect what I really want & 3.75 & Agree/Satisfied/High \\
\hline 3. I feel my choices on my job express who really, I am & 3.72 & Agree/Satisfied/High \\
\hline 4. I feel I have been doing what really interests me in my job & 3.90 & Agree/Satisfied/High \\
\hline Overall & $\mathbf{3 . 7 5}$ & Agree/Satisfied/High \\
\hline
\end{tabular}

Legend:

4.21-5.00

Strongly agree/ Very satisfied

Very High

$3.41-4.20$

Agree/ satisfied/

High

$2.61-3.40$

Somewhat agree/ Somewhat satisfied

Moderate

$1.81-2.60$

Disagree/ dissatisfied

Low/High

$1.00-1.80$

Strongly disagree/very dissatisfied

Very Low/Very High

As gleaned from the table, the data reveals that over all, the autonomy satisfaction of employees is 3.75 which is interpreted as high or satisfied. Even when the questions are taken singly, the employees agree that at work, they have the choice and freed om (3.64), they feel that their decisions on their job reflect what they really want (3.75), they feel that their choice on their job expresses who they are (3.72) and they feel that they have been doing what really interest them in their job (3.90).

1b. What is the basic psychological need satisfaction of employees of Divine Word Colleges in Ilocos Region in terms of Relatedness?

Table.1b. Relatedness satisfaction

\begin{tabular}{|l|l|l|}
\hline Relatedness Satisfaction & $\mathrm{X}$ & $\mathrm{DR}$ \\
\hline 1. I feel that the people I care at work about also care about me & 3.77 & Agree/Satisfied/High \\
\hline $\begin{array}{l}\text { 2. I feel connected with people who care for me at work and for whom I } \\
\text { care at work }\end{array}$ & 3.75 & Agree/Satisfied/High \\
\hline $\begin{array}{l}\text { 3. At work, I feel close and connected with other people who are } \\
\text { important to me }\end{array}$ & 3.88 & Agree/Satisfied/High \\
\hline 4. I experience a warm feeling with the people I spend time with at work & 3.94 & Agree/Satisfied/High \\
\hline Overall & 3.84 & Agree/Satisfied/High \\
\hline
\end{tabular}

Legend

4.21-5.00

Strongly agree/ Very satisfied

Very High

$3.41-4.20$

Agree/ satisfied/

High

$2.61-3.40$

Somewhat agree/ Somewhat satisfied

Moderate

$1.81-2.60$

Disagree/ dissatisfied

Low/High

$1.00-1.80$

Strongly disagree/very dissatisfied

Very Low/Very High

In consistence with their evaluation on the autonomy satisfaction, the employees also have the same level of relatedness satisfaction, that they are satisfied. As it is presented on the table, overall the employees have 3.84 in terms of relatedness satisfaction which means that overall employees agree that they are satisfied. Even when the questions are taken singly, the employees feel that the people they care at work care about them too (3.77), employee feel connected with each other at work (3.75), they feel close and connected to people who are important to them (3.88), and they experience warm feeling with other people at their workplace (3.94).

1c. What is the basic psychological need satisfaction of employees of Divine Word Colleges in Ilocos region in terms of competency? 
Table.1c. Competency satisfaction

\begin{tabular}{|l|l|l|}
\hline competency Satisfaction & X & DR \\
\hline 1. I feel confident that I can do things well on my job & 3.98 & Agree/Satisfied/High \\
\hline $\begin{array}{l}\text { 2. At work, I feel capable at what I do } \\
\text { When I am at work, I feel competent to achieve my goals }\end{array}$ & 4.05 & Agree/Satisfied/High \\
\hline 3. When I am at work, I feel competent to achieve my goals & 4.04 & Agree/Satisfied/High \\
\hline 4. In my job, I feel I can successfully complete difficult task & 3.90 & Agree/Satisfied/High \\
\hline Overall & 3.99 & Agree/Satisfied/High \\
\hline
\end{tabular}

Legend

$4.21-5.00$

$3.41-4.20$

$2.61-3.40$

$1.81-2.60$

$1.00-1.80$
Strongly agree/ Very satisfied

Agree/ satisfied/

Somewhat agree/ Somewhat satisfied

Disagree/ dissatisfied

Strongly disagree/very dissatisfied
Very High

High

Moderate

Low/High

Very Low/Very High

In terms of competency satisfaction, the data reveals the same interpretation that employees are satisfied. As it is revealed on the table, the overall, employees agree that their competency need is satisfied as it is reflected in its mean of 3.99. Even when individual questions are examined, it shows that the employees agree that they feel confident that they can perform their job (3.98), they feel capable of their work and can achieve their goals (4.05), they feel competent to achieve their goals (4.04) and they can successfully complete difficult task (3.90).

Table.1d. Summary

\begin{tabular}{|l|l|l|}
\hline Summary on Basic psychological Need Satisfaction & X & DR \\
\hline Autonomy & 3.75 & Agree/Satisfied/High \\
\hline Relatedness & 3.84 & Agree/Satisfied/High \\
\hline Competency & 3.99 & Agree/Satisfied/High \\
\hline Overall & $\mathbf{3 . 8 6}$ & Agree/Satisfied/High \\
\hline
\end{tabular}

In summary, the data reveals that overall employees' basic psychological need satisfaction are considered high. It means that employees agree that their autonomy needs (3.75), relatedness need (3.84), and competency need (3.99) are satis fied.

Problem 2: What is the basic psychological need frustration of employees of Divine Word Colleges in Ilocos Region in terms of autonomy?

Table.2a. Autonomy frustration

\begin{tabular}{|l|l|l|}
\hline Autonomy Frustration & X & DR \\
\hline 1. Most of things I do on my job feel like, "I have to & 3.61 & Agree/Frustrated \\
\hline 2. I feel forced to do many things on my job I wouldn't choose to do & 2.80 & Somewhat agree/somewhat frustrated \\
\hline 3. I feel pressured to do many things on my job & 2.94 & Somewhat agree/somewhat frustrated \\
\hline 4. My daily activities at work feel like a chain of obligations & 3.06 & Somewhat agree/somewhat frustrated \\
\hline Overall & $\mathbf{3 . 1 0}$ & $\begin{array}{l}\text { Somewhat agree/somewhat } \\
\text { frustrated }\end{array}$ \\
\hline
\end{tabular}

Legend:

4.21-5.00

$3.41-4.20$

$2.61-3.40$

$1.81-2.60$

$1.00-1.80$
Strongly agree/Very frustrated

Agree/frustrated

Somewhat agree/somewhat frustrated

Disagree/not frustrated

Strongly disagreel not frustrated at all.
Very high

High

Moderate

low

Very low 
As it is drawn from the data, the data reveals that overall, the employees somewhat agree that they are somewhat frustrated in terms of their autonomy need satisfaction as indicated by its mean average of 3.10. Even when the questions are taken singly, employees feel that most of the things they do on their job feel like, "they have to" (3.61), they feel forced to do many things on their job they wouldn't choose to do (2.80), they feel pressured to do many things on their job (2.94) and they feel that their daily activities at their work is like a chain of obligations (3.06).

Problem 2b. What is the basic psychological need frustration of employees of Divine Word Colleges in Ilocos Region in terms of relatedness?

Table.2b. Relatedness frustration

\begin{tabular}{|l|l|l|}
\hline Relatedness Frustration & $\mathrm{X}$ & $\mathrm{DR}$ \\
\hline 1. I feel excluded from the group I want to belong to at work & 2.15 & Disagree/not frustrated \\
\hline $\begin{array}{l}\text { 2. I feel that people who are important to me at work are cold } \\
\text { and distant towards me }\end{array}$ & 2.14 & Disagree/Not frustrated \\
\hline $\begin{array}{l}\text { 3. I have the impression that people I spend time with at work } \\
\text { dis like me }\end{array}$ & 2.16 & Disagree/not frustrated \\
\hline 4. I feel the relationship I have at work are just superficial & 2.23 & Disagree/not frustrated \\
\hline Overall & 2.17 & Disagree/not frustrated \\
\hline
\end{tabular}

Legend

$\begin{array}{lll}4.21-5.00 & \text { Strongly agree/Very frustrated } & \text { Very high } \\ 3.41-4.20 & \text { Agree/frustrated } & \text { High } \\ 2.61-3.40 & \text { Somewhat agree/somewhat frustrated } & \text { Moderate } \\ 1.81-2.60 & \text { Disagree/not frustrated } & \text { low } \\ 1.00-1.80 & \text { Strongly disagree/ not frustrated at all. } & \text { Very low }\end{array}$

Contrary to the autonomy need frustration, relatedness need frustration seems to be otherwise. Employees feel that they are $n$ ot frustrated in terms of relatedness need. Taken from the data on the table, it shows that overall, the employees disagree that they are frustrated (2.17) which is interpreted as disagree. It just means that they are not frustrated but satisfied. Such evaluation is supported by the evaluation of different question that the employees disagree that they are excluded from the group (2.15), they disagree that people who are important to them at work are cold and distant toward them (2.14), they disagree that people th ey spend time with at work dislike them (2.16) and they disagree that the relationship they have at work is just superficial (2.17).

Problem 2c: What is the basic psychological need frustration of employees of Divine Word Colleges in Ilocos Region in terms of competency?

Table.2c. Competency frustration

\begin{tabular}{|l|l|l|}
\hline Competency Frustration & $\mathrm{X}$ & DR \\
\hline $\begin{array}{l}\text { 1. When I am at work, I have serious doubts about whether I can } \\
\text { do things well }\end{array}$ & 2.66 & $\begin{array}{l}\text { Somewhat agree/ somewhat } \\
\text { frustrated }\end{array}$ \\
\hline 2. I feel dis appointed with my performance in my job. & 2.38 & Disagree/not frustrated \\
\hline 3. I feel insecure about my abilities on my job & 2.28 & Disagree/not frustrated \\
\hline $\begin{array}{l}\text { 4. When I am working, I feel like a failure because of the } \\
\text { mistakes I make }\end{array}$ & 2.21 & Disagree/not frustrated \\
\hline Overall & 2.38 & Disagree/not frustrated \\
\hline
\end{tabular}

Legend

4.21-5.00

3.41-4.20

$2.61-3.40$

$1.81-2.60$

$1.00-1.80$
Strongly agree/Very frustrated

Agree/frustrated

Somewhat agree/somewhat frustrated

Disagree/not frustrated

Strongly disagree/ not frustrated at all. Very low
Very high

High

Moderate

low 
The evaluation on the basic psychological need frustration in terms of competency need frustration shows the same evaluation as the other two basic psychological need frustration such as autonomy need, and relatedness need frustration. As it is drawn from the data gathered, it shows that overall, the employees are not frustrated in terms of their competency need as it is revealed by its mean average of 2.38 which is understood as not frustrated. It just means that the employees are satisfied with their compete ncy needs. Even when taken them singly, data shows that the employees disagree that they feel disappointed with their performance in their job (2.38), they disagree that they feel insecure about their abilities on their job (2.28), and they disagree too that they feel like a failure because of the mistake they make (2.21). However, they somewhat agree that they have doubts about their capability to do things well (2.66).

Table.2d. Summary

\begin{tabular}{|l|l|l|}
\hline Summary on Need Frustration & $\mathrm{X}$ & DR \\
\hline Autonomy & 3.10 & Somewhat agree/ somewhat frustrated \\
\hline Relatedness & 2.17 & Disagree/not frustrated \\
\hline Competency & 2.38 & Disagree/not frustrated \\
\hline Overall & $\mathbf{2 . 5 5}$ & Disagree/not frustrated \\
\hline
\end{tabular}

Legend

4.21-5.00

$3.41-4.20$

Strongly agree/Very frustrated

Very high

$2.61-3.40$

Agree/frustrated

Somewhat agree/somewhat frustrated

High

$1.81-2.60$

Disagree/not frustrated

Moderate

$1.00-1.80$

Strongly disagreel not frustrated at all. Very low

In summary, it reveals that overall the employees are not frustrated in terms of their basic psychological need satisfaction. They are not frustrated with their relatedness need (2.17) and competency need (2.38). In other words, they are satisfied with those two needs. However, the employees somewhat agree that their need for autonomy is not satisfied or somewhat they are frustrated along such need as it is revealed by its mean average of 3.10 .

Problem 3: What is the work engagement of employees of Divine Word Colleges in Ilocos region?

Table.3: Work Engagement.

\begin{tabular}{|c|c|c|}
\hline Work Engagement & $\mathrm{X}$ & DR \\
\hline 1. I am willing accept change & 4.30 & Strongly agree \\
\hline 2. I am willing to take on new task as needed & 4.20 & Agree/high \\
\hline 3. I take the initiative to help other employees when the need arises & 4.19 & Agree \\
\hline 4. I keep going even when things get tough & 4.08 & Agree \\
\hline 5. I adapt quickly to difficult situations & 3.85 & Agree \\
\hline 6. When at work, I am completely focused on my job duties & 4.06 & Agree \\
\hline 7. I pro-actively identify future challenges and opportunities & 3.90 & Agree \\
\hline 8. I am determined to give my best effort at work each day & 4.24 & Strongly Agree \\
\hline 9. I am often so involved in my work that the day goes by very quickly & 3.93 & Agree \\
\hline 10. I get excited about going to work & 3.86 & Agree \\
\hline 11. I feel completely involved in my work & 4.01 & Agree \\
\hline 12. I am inspired to meet my goals at work & 4.11 & Agree \\
\hline 13. I understand the strategic goals of my organization & 4.03 & Agree \\
\hline 14. I see to it that I work to the best I can to meet the objective of my organization & 4.11 & Agree \\
\hline 15. I see to it that what I do is in line with the organization's objectives & 4.08 & Agree \\
\hline 16. I am proud to be part of the team & 4.10 & Agree \\
\hline 17. My team inspire me to work hard every day & 3.97 & Agree \\
\hline 18. My team is always helping me to complete my work & 3.94 & Agree \\
\hline 19. I have good information about my work & 3.96 & Agree \\
\hline 20. I have good understanding of informal structures and processes at the & 3.85 & Agree \\
\hline
\end{tabular}




\begin{tabular}{|l|l|l|}
\hline organization. & & \\
\hline Overall & $\mathbf{4 . 0 4}$ & Agree/High \\
\hline
\end{tabular}

Legend:

4.21-5.00

$3.41-4.20$

$2.61-3.40$

$1.81-2.60$

$1.00-1.80$

Strongly agree
Agree/
Somewhat agree
Disagree
Strongly disagree

$$
\begin{aligned}
& \text { Very High } \\
& \text { High } \\
& \text { Moderate } \\
& \text { Low/High }
\end{aligned}
$$

Very Low/Very High

As reflected from the data gathered, it shows that overall, the work engagement of employees is considered high as it is indicated by its overall mean average of 4.04 which is seen as high. Even when they are taken singly, it reveals that the employees are willing to take initiative to help other employees (4.19), they keep going even when things get tough (4.08), adapt quickly with difficult situation (3.85), focus on their job (4.06), pro-actively identify future challenges and opportunities (3.90), are involved in their work every day (3.93), are excited about going to their work (3.86), are inspired to meet their goals at work (4.11), understand strategic goals of the organization (4.03), are willing to do their best to contribute to the attainment of organization's objectives (4.11), do their work in line with the organization's objectives (4.08), are proud to be part of the team (4.10), are inspired by their team (3.97), acknowledge the role of team to their work (3.94), have good information about their work (3.96) and have good understanding about the structures and processes of the organization (3.85).

Problem 4: Is there a relationship between basic psychological need satisfaction and work engagement?

Table.4: Correlation

\begin{tabular}{|l|l|}
\hline \multicolumn{2}{|l|}{ Relationship between basic psychological need satisfaction and work engagement } \\
\hline Autonomy & $0.50539^{*}$ \\
\hline Relatedness & $0.34338^{*}$ \\
\hline Competence & $0.57173^{*}$ \\
\hline As a whole & $0.47350^{*}$ \\
\hline
\end{tabular}

* Significant at 0.05 level (2- tailed),

As it is revealed on the correlation table, the data shows that as a whole, there is a correlation between basic psychological need satisfaction and work engagement at 0.05 level of significance. Taken them singly, autonomy, relatedness and competence need satisfactions are all correlated to work engagement.

Problem 5: is there a relationship between basic psychological need frustration and work engagement?

Table.5: Correlation

\begin{tabular}{|l|l|}
\hline Relationship between basic psychological need frustration and work engagement \\
\hline & \\
\hline Autonomy & 0.0663 \\
\hline relatedness & $-0.2580^{*}$ \\
\hline competence & -0.2008 \\
\hline As a whole & -0.1308 \\
\hline
\end{tabular}

*Significant at 0.05 level (2- tailed)

In the contrary, basic psychological need frustration seems to be otherwise. As it is shown in the data, it reveals that as a whole, basic psychological need frustration does not correlate to the work engagement. However, taking them singly, autonomy and competence need frustrations do not correlate to the work engagement, but relatedness need frustration does correlate to work engagement at 0.05 level of significance.

\section{CONCLUSION}

Based on the findings, the study concludes that over all basic psychological needs of employees of Divine Word College of employees are satisfied. They are satisfied with their autonomy need, relatedness need, and competency need. However, they somewhat agree that they are to some extent frustrated along autonomy, though overall employees are not frustrated with their three basic psychological needs. 
In terms of work engagement, the finding shows that employees have a high work engagement.

The finding also reveals that there is a correlation between basic psychological need satisfaction and work engagement, while basic psychological need frustration, as a whole, does not correlate to the work engagement except relatedness need frustration.

\section{RECOMMENDATION}

Based on the findings, the study recommends that the management need to improve work environment in which autonomy, relatedness and competence needs are nurtured to motivate employees to engage in their job daily.

\section{REFERENCES}

[1] Abun, D \& Magalanez, T. (2018).Psychological need satisfaction at work of faculty and employees of divine word colleges in region I, Philippine and their work engagement. International Journal of Applied Research, Vol. 4, Is sue 3, pp. 21-30.

[2] Alderfer, C. (1969). Organizational Behavior and Human Performance: An Empirical test of a new theory of human needs. Science Direct.

[3] Ariola, M.M. (2006). Principles and Methods of Research. Manila: Rex Book Store.

[4] Arshadi, N. (2010). Basic need satisfaction, work motivation, and job performance in an industrial company in Iran. Procedia Social and Behavioral Sciences 5 (2010) 1267-127.

[5] Bakker, A.B. Albrecht, S., \& Leiter, M.P. (2011). Key Questions Regarding Work Engagement. European Journal of Work and Organizational Psychology. Retrieved from http://www.arnoldbakker.com/workengagement.php.

[6] Baumeister, R., \& Leary, M.R., (1995). The Need to belong: Desire for interpersonal attachment as a fundamental human motivation. Psychological Bulletin. Vol. 117, pp. 497-529.

[7] Broeck, V.D., Maarten, A.V., De Wette, H. \& Lens, W. (2008). Explaining the Relationship between job characteristics, burnout, and engagement: The role of basic psychological need satisfaction. International Journal of work, Health, \& Organizations, Vol. 22, 2008, Is sue 3.

[8] Broni, A.A. (2012). Relationship between Motivation and Job Performance at the University of Mines and technology, Tarkwa, Ghana. Creative Education, Vol. 3, No. 3, pp. 309-314.
[9] Busch, H. \&Hofer, J. (2011). Satisfying One's Needs for Competence and Relatedness. Personality and Social Psychology Bulletin. Vol. 37, Is sue 9, 2011.

[10] Collier, J. (n.d). What is Autonomy? Department of Philosophy. University of Newcastle, Australia. Retrieved from http://cogprints .org/2289/3/autonomy.pdf.

[11] Cooper, B.B. (2016). The Key to Happiness at Work Isn't Money-It's Autonomy. Quartz. Retrieved from https://qz.com/676144/why-its-your-call-is-the-bestthing-you-can-say-to-keep-employees-happy/

[12] deCharms, R. (1968). Personal Causation. New York: Academic Press.

[13] Deci, E. L. (1975). Intrinsic motivation. New York: Plenum.

[14] Deci, E. L., \& Ryan, R. M. (1985). Intrinsic motivation and self-determination in human behavior. New York: Plenum.

[15] Deci, E. L., \& Ryan, R. M. (1975). Intrinsic Motivation. New York: Plenum.

[16] Deci, E. L. (1971). Effects of externally mediated rewards on intrinsic motivation. Journal of Personality and Social Psychology, 18, 105-115.

[17] Deci, E.E. \& Ryan, R.M. (2000). Self-Determination Theory and The Facilitation of Intrinsic Motivation, Social development and Well-Being. American Psychological Association, Vol. 55, no. 1, pp. 68-78.

[18] Deci, E. L. (1971). "Effects of externally mediated rewards on intrinsic motivation". Journal of Personality and Social Psychology. 18: 105115. doi:10.1037/h0030644.

[19] Deci, E. L., \& Ryan, R. M. (2000). The "what" and "why" of goal pursuits: Human needs and the selfdetermination of behavior. Psychological Inquiry, 11, 227-268.

[20] Deci, E.L., Ryan, R.M., (Human Autonomy: The Basis for True Self-Esteem. In M. Kernis (Ed.), Efficacy, Agency, and Self-Esteem. New York: Plenum.

[21] Dickinson, L. (1995). Autonomy and Motivation a Literature Review. System, Vol. 23, Issue, 2, pp. 165174.

[22] Furnham, A. (1994). Personality at Work: The Role of Individual Differences in the Workplace. London: Routledge.

[23] Gagn'e, M. (2003). The Role of Autonomy Support and Autonomy Orientation in Prosocial Behavior Engagement. Motivation and Emotion, Vol. 27, No. 3, September 2003. 
[24] Harter, S. (1978). Effectance motivation are reconsidered: toward a developmental model. Human Development, Vol. 1, pp. 661-669.

[25] Herzberg, Frederick; Mausner, Bernard; Snyderman, Barbara B. (1959). The Motivation to Work (2nd ed.). New York: John Wiley. ISBN 0471373893.

[26] Kruse, K. (2012). What is Employee Engagement. Forbes. Retrieved from https://www.forbes.com/sites/kevinkruse/2012/06/22/e mployee-engagement-what-and-why/\#5e11edf7f372.

[27] Legault, L. (2016). The Need for Autonomy. New York: Springer International Publishing.

[28] Legault, L. (2017). The Need for Competence. New York: Springer International Publishing.

[29] Lickerman, A. (2012). The Desire for Autonomy: Why our need to make choices is so crucial to our happiness. Psychology Today. Retrieved from https://www.ps ychologytoday.com/us/blog/autonomy in-world/201205/the-desire-autonomy

[30] Maslow, A. H. (1943). A theory of human motivation. Psychological review,50(4), 370.

[31] May, D. R., Gilson, R. L., \& Harter, L. M. (2004). The psychological conditions of meaningfulness, safety and availability and the engagement of the human spirit at work. Journal of Occupational and Organizational Psychology, 77, 11-37.

[32] McClelland, D. Human Motivation, 1988. Cambridge University Press.

[33] Mensah, E.B.K., \& Tawiah, K.A. (2013). Employee Motivation and Work Performance: A Comparative Study of Mining Industry in Ghana. Journal of Industrial Engineering and Management. Vol. 9(2), pp. 255-309.

[34]Molix, L.A. \&Nichols, C.P. (2013). Satisfaction of basic psychological needs as a mediator of the relationship between community esteem and wellbeing. International Journal of Wellbeing, 3(1), 20-34. doi:10.5502/ijw. v3i1.2.

[35]Molinari, L. \& Maneli, C. (2018). Basic psychological needs and school engagement: a focus on justice and agency. Social Psychology of Education, Volume 21, Is sue 1, pp 157-172.

[36] MSG. (n.d). Importance of Motivation. MSG: Management Study Guide. Retrieved from https://www.managementstudyguide.com/importance_ of_motivation.htm

[37] Nasiboy, A. (2015). Impact of Employee Motivation on Performance or Productivity. Retrieved from https://www.linkedin.com/pulse/impact-employee-

motivation-performance-productivity anar-nesibov/

[38] Perry, N.E., Klassen, M., \& Frenzel, A.C. (2012). Teachers' Relatedness with the Students: An Underemphasized Component of Teachers' Basic Psychological Needs. American Psychological Association, 104(1):150-165. DOI: 10.1037/a0026253.

[39] Quigley, S.P. (2015). Existence, Relatedness and Growth (ERG) Theory of Motivation. Value Transformation LLC. Retrieved from https://www.valuetransform.com/existencerelatedness-growth-erg-theory-motivation/

[40] Reeve, J., Ryan, R. M., \& Kim, A. (2009). Can selfdetermination theory explain what underlies the productive, satisfying learning experiences of collectivistically oriented Korean students? Journal of Educational Psychology, 101(3), 644-661.

[41] Rigby, S., \& Ryan, R. M. (2011). Games and The Need for Relatedness. Glued to games how video games draw us in and hold us spellbound (). Santa Barbara, Calif.: ABC-CLIO.

[42] Ryan, R.M. \& Deci, E.L. (2000). Intrinsic and Extrinsic Motivations: Classic Definitions and New Directions. Educational Psychology, Vol. 25, Issue, 1, pp.54-67.

[43] Ryan, R. M., \& Deci, E. L. (2000). The darker and brighter sides of human existence: Basic psychological needs as a unifying concept. Psychological Inquiry, 11, 319-338.

[44] Ryan, R. M.; Deci, E. L. (2000). "Self-determination theory and the facilitation of intrinsic motivation, social development, and well-being". American Psychologist. 55 (1): $\quad$ 68-78. 066X.55.1.68.

[45] Ryan, R. M. (1995). Psychological needs and the facilitation of integrative processes. Journal of Personality, 63, 397-427.

[46] Sagor, R. (2003). Motivating Teachers and Students in an Era of Standards. Association for Supervision and Curriculum Development (ASCD). Retrieved from http://www.ascd.org

[47] Sarı, I. (2015). Satisfaction of Basic Psychological needs and Goal Orientation in Young athletes: A Test of Basic Psychological Needs Theory. Kinesiology 47(2015) 2:159-168.

[48] Schaufeli, W.B., Salanova, M., Romá, G., V., \& Bakker, A.B. (2002). The measurement of Engagement and burnout: A confirmative analytic approach. Journal of Happiness Study, 3: 71-92, 2002. 
[49] Schaufeli, W.B. (2011). Work Engagement: What do

We Know? Paper presented at International

Works hop, Timis oara, 2011.

[50] Schunk, D.H. (2014). Motivation in Education:

Theory, Research and Application. New York:

Pearson Education, Inc.

[51] Sheldon1, K.M. \&Filak, V. (2008). Manipulating autonomy, competence, and relatedness support in a game-learning context: New evidence that all three needs matter. British Journal of Social Psychology (2008), 47, 267-283.

[52] Shuck, B. \&Zigarmi, D. (2015). Psychological needs, engagement, and Work Intentions. European Journal of Training and Development, Vol. 39 Issue 1 pp. 2 21.

[53] Singh, S. (2011). Employee Motivation and Job Performance - Exploring the Relationship. Unpublished Thesis. Prifysgol Bangor University, Wales. Scribd.

[54] Sugarman, S. (1990). Piaget's Construction of the Child's Reality. Cambridge University Press. ISBN 9780521379670.

[55] Suzuki, T. \&Nishimura, T. (2016). Basic Psychological Need Satisfaction and Frustration in Japan: Controlling for the Big Five Personality Traits. Japanese Psychological Research, Vol. 58, No. 4, pp. 320-331. https://doi.org/10.1111/jpr.12131.

[56] Vallerand, R.J. \& Reid, G. (1984). "On the causal effects of perceived competence on intrinsic motivation: A test of cognitive evaluation theory". Journal of Sport Psychology. 6: 94-102.

[57] Vansteenkiste, M., \& Ryan, R. M. (2013). On psychological growth and vulnerability: Basic psychological need satisfaction and need frustration as a unifying principle. Journal of Psychotherapy Integration, 3, 263-280.

[58] White, R. W. (1959). Motivation reconsidered: The concept of competence. Psychological Review, 66, 297-333.

[59] Xiang, P., Ağbuğa, B., Liu, J., \& McBride, R.E. (2017). Relatedness Need Satisfaction, Intrinsic Motivation, and Engagement in Secondary School Physical Education. Huma Kinetic Journal. Vol. 36, Is sue 3, pp. 340-352. 